\title{
Assessment of Physicochemical Characteristics of Produced Water from Terminals of Some Oil Industry Facilities in Nigeria
}

\section{*11OBUNWO CC; CHUKWUDI C}

\author{
Department of Chemistry, Rivers State University of Science and Technology, \\ Nkpolu-Oroworukwo, Port Harcourt \\ *Corresponding author: obunwo.charles@ust.edu.ng
}

\begin{abstract}
This study evaluated the physico-chemical characteristics, total hydrocarbon concentration (THC) and some heavy metal levels of produced water from terminals of two oil industry facilities in Nigeria, using standard methods. Appropriate sample bottles were used in the collection of samples for analyses of BOD, other physico-chemical characteristics, total hydrocarbon and heavy metals. The samples were preserved accordingly and transported to the laboratory in ice - packed coolers. The levels of the physico-chemical properties of produced water in the two locations, showed that mean temperature, $\mathrm{pH}$, TDS, TSS, salinity and turbidity levels were: $24.40 \pm 0.35^{\circ} \mathrm{C}-25.50 \pm 0.35^{\circ} \mathrm{C} ; 7.49 \pm 0.28-7.89 \pm 0.30 ; 8428 \pm 2332 \mathrm{mg} / \mathrm{l}-$ $9205 \pm 2100 \mathrm{mg} / \mathrm{l} ; 8.50 \pm 3.40 \mathrm{mg} / \mathrm{l}-14.30 \pm 5.10 \mathrm{mg} / \mathrm{l} ; 6108 \pm 1250 \mathrm{mg} / \mathrm{l}-7422 \pm 2280 \mathrm{mg} / \mathrm{l}$ and $16.00 \pm 5.00 \mathrm{NTU}-37.00 \pm 9.60 \mathrm{NTU}$ respectively. DO and BOD levels were respectively $3.07 \pm 0.40 \mathrm{mg} / \mathrm{l}-3.29 \pm 0.40 \mathrm{mg} / \mathrm{l}$ and $1.46 \pm 0.38 \mathrm{mg} / \mathrm{l}-1.72 \pm 0.48 \mathrm{mg} / \mathrm{l}$. COD levels did not vary between the two locations. Mean TOC levels ranged between $0.05 \pm$ $0.02 \mathrm{mg} / \mathrm{l}$ and $0.06 \pm 0.02 \mathrm{mg} / \mathrm{l}$ while mean THC ranged between $4.72 \pm 1.59 \mathrm{mg} / \mathrm{l}$ and $36.90 \pm$ $3.03 \mathrm{mg} / \mathrm{l}$. The levels of the nutrient characteristics of nitrate, phosphate and sulphate ranged as follows: $\mathrm{NO}_{3}{ }^{-}(1.90 \pm 1.16 \mathrm{mg} / \mathrm{l}-2.50 \pm 0.26 \mathrm{mg} / \mathrm{l}) ; \mathrm{PO}_{4}{ }^{3-}(0.52 \pm 0.12 \mathrm{mg} / \mathrm{l}-1.07 \pm 0.12 \mathrm{mg} / \mathrm{l})$ and $\mathrm{SO}_{4}{ }^{2-}(14.40 \pm 4.57 \mathrm{mg} / \mathrm{l}-21.70 \pm 2.75 \mathrm{mg} / \mathrm{l})$. Levels of trace metals $(\mathrm{Pb}, \mathrm{Ni}, \mathrm{V}, \mathrm{Cd}, \mathrm{Hg}$ and $\mathrm{Cr}$ ) were below detection limits. However, the concentration of $\mathrm{Fe}$ ranged between $0.53 \pm$ $0.11 \mathrm{mg} / 11.06 \pm 0.26 \mathrm{mg} / \mathrm{l}$. With the exception of salinity, TDS and TSS, the levels of other physico- chemical characteristics including the trace metals were within the permissible limits set out by Nigeria's Department of Petroleum Resources (DPR). ( ) JASEM
\end{abstract}

\section{http://dx.doi.org/10.4314/jasem.v19i2.2}

KEY WORDS: Physico- chemical characteristics, Produced water, oil terminals, Heavy metals, oil industry facility.

\section{Introduction}

Wastes of different types and characteristics are largely generated in the oil and gas industry. Of these, liquid wastes constitute a significant percentage.

In most crude oil-bearing formations, the rocks are generally permeated with fluids such as water, oil, gas or some combination of these fluids (Amyx et al. 1960).Water and other fluids in the reservoir, when brought to the surface, constitute the produced water.

It is, by far, the largest volume byproduct or waste stream associated with oil and gas production (Mofat and Olof, 1995). Indeed, both intentional and unintentional discharges of produced waters have been associated with oil production.

Although attention on environmental degradation has always been focused on oil spillage, there is abundant evidence to show that much of the degradation comes from petroleum related facilities and installations (Ibiebele, 1986; Dessel and Omuka, 1994 Mofat and Olof, 1995 and Obunwo et al., 2006).

An investigation carried out by Environmental Rights Action (ERA, 1998) indicated that the refineries and terminals discharge largely untreated effluents (which include produced water) in Port Harcourt and Warri areas which are in the Niger Delta region.

This study is thus aimed at assessing the physicochemical characteristics of produced water from terminals of some oil industry facilities in the Niger Delta, Nigeria and to compare the data obtained with standards set out by the regulatory bodies in the country, since both intentional and unintentional discharges of produced waters have been associated with oil production. 
A number of studies have been conducted in the USA on produced water from different oil and gas platforms (Neff, 1998; Jacobs et al., 1992; Cox 1992 and Cline 1998). The researchers observed that waters discharged from gas and condensate platforms were far more toxic than the produced waters discharged from oil platforms. They also noted that produced water contained varying concentrations of Barium, Beryllium, Cadmium, Chromium, Copper, Iron, Lead, Nickel, Silver, Zinc as well as small amounts of natural radioactive materials.

In Nigeria, studies by Oboh et al., (2009), noted that discharged produced waters had high metal ions and total hydrocarbon concentrations. Okoro (2010), on the other hand, demonstrated that produced water discharges in near shore environment in the Niger Delta led to substantial accumulation of hydrocarbons and microorganisms up to $500 \mathrm{~m}$ from discharge points. Isehunwa and Onovae (2011) observed that the produced water discharged into the environment in the studied areas had high levels of oil and grease as well as TDS and TSS.

The coastal aquatic ecosystems of the Niger Delta region of Nigeria have of recent received much attention because of the considerable man-mediated perturbations these fragile environments have been subjected to. In this study, two key oil centres in the Niger delta region, Warri and Port Harcourt, were chosen as the sampling areas. Produced waters from a number of oil industry facilities in these areas were sampled.

\section{MATERIALS AND METHODS}

Samples of produced water were obtained from two (nearshore) terminals in Port Harcourt and Warri of the Niger Delta. Sampling was done in accordance with established guidelines and procedures (APHA, 2005). Samples for BOD analysis were collected in amber glass bottles while samples for other physicochemical parameters were collected in plastic containers. Samples for hydrocarbon analysis were collected in 1litre glass bottles. For measurements of heavy metal levels, few drops of concentrated nitric acid were added to the produced water collected in sample bottles. Sampling was carried out monthly for 12 months (January - December, 2012), to cover both wet and dry season periods.

In situ measurements of $\mathrm{pH}$, temperature, conductivity, dissolved oxygen and turbidity were carried out with the thermometer and $\mathrm{pH}$, conductivity/TDS, DO and Turbidity meters respectively. Analyses of other parameters, Salinity, Total Dissolved Solids (TDS), Total Suspended
Solids (TSS), Dissolved Oxygen (DO), Biochemical Oxygen Demand $\left(\mathrm{BOD}_{5}\right)$, Chemical Oxygen Demand (COD), Total Organic Carbon (TOC), Anions (phosphate, sulphates and nitrates), Metals ( Chromium, Copper, Iron, Lead, Zinc, Nickel, Cadmium, Mercury and Vanadium) and Total Hydrocarbon Concentration (THC), followed standard methods (APHA, 2005) in the laboratory.

\section{RESULTS AND DISCUSSION}

The results of the physico-chemical values at the two terminals as well as the permissible standards in Nigeria (DPR, 2002) are presented in Table 1. The mean $\mathrm{pH}$ values ranged between $7.49 \pm 0.28$ and 7.89 \pm 0.30 ; the higher $\mathrm{pH}$ being recorded at the Warri terminal. Although, there was no significant difference $(\mathrm{p}<0.05)$ in $\mathrm{pH}$ at the different terminals, the apparent difference might have arisen from inherent geochemical properties of the formations. The $\mathrm{pH}$ values were, however, within permissible limits $(6.5-8.5)$, implying that during the chemical treatment of the formations during production, $\mathrm{pH}$ was not adversely impacted.

Similarly, temperature, TOC, THC, nutrient parameters and the oxygen- related characteristics did not vary widely and were within the permissible limits. This trend is largely attributed to the large volume of water within the recipient environment which brings about massive dilution of the discharged produced water.

The mean TDS values indicated that higher levels were recorded at the Port Harcourt terminal (9205 \pm $2100 \mathrm{mg} / \mathrm{l})$ than at the Warri terminal (8428 \pm $2332 \mathrm{mg} / \mathrm{l})$. These levels are, however, higher than the permissible limits $(5000 \mathrm{mg} / \mathrm{l})$ for nearshore area. The leaching of secondary salts might be contributory to the high levels of TDS in the produced water (Onojake, 2011). Discharge of such produced water with high levels of TDS into freshwater systems has the potential of affecting activities in the aquatic environment (Tubonimi et al., 2010).

Mean salinity values were also higher at the Port Harcourt terminal $(7422 \pm 2280 \mathrm{mg} / \mathrm{l})$ than at the Warri terminal $(6108 \pm 1250 \mathrm{mg} / \mathrm{l})$. Salinity values at the two terminals were significantly different $(p>0.05)$ and were also higher than the permissible limit $(2000 \mathrm{mg} / \mathrm{l})$. These results are in good agreement with earlier studies (Otto et al., 1990; Jacobs et al., 1992 and Cline, 1998) which had indicated that most produced waters were more saline than sea water.

On the other hand, although both levels exceeded the permissible limits $(<15.0 \mathrm{NTU})$, mean turbidity levels were higher at the Warri terminal $(37.00 \pm 9.60$ 
NTU) than at the Port Harcourt terminal (16.50 \pm 5.00NTU).

Mean Total Hydrocarbon Concentrations (THCs) varied widely at the two terminals. Concentration at the Warri terminal $(36.90 \pm 3.03 \mathrm{mg} / \mathrm{l})$ was markedly higher than that at the Port Harcourt terminal (4.72 \pm $1.59 \mathrm{mg} / \mathrm{l})$ and also exceeded the permissible limit $(20.0 \mathrm{mg} / \mathrm{l})$. Factors that affect the concentration of hydrocarbon in produced water include density, interfacial tension and type/efficiency of chemical treatment (Ali, et al,. 1999). These factors might be responsible for the marked variation of $\mathrm{THC}$ at the two terminals.

Although high levels of metal ions have been reported in produced water in a Nigerian oil facility
(Oboh et al, 2009), there was no evidence of high metal levels in the terminals of the two oil facilities in Port Harcourt and Warri during the study period. With the exception of $\mathrm{Fe}$, the metal levels were generally below the detection limits of the Atomic Absorption Spectrophotometer $(0.001 \mathrm{mg} / \mathrm{l})$. The mean Fe levels at the two terminals were Port Harcourt $(1.06 \pm 0.26 \mathrm{mg} / \mathrm{l})$ and Warri $(0.53 \pm$ $0.11 \mathrm{mg} / \mathrm{l})$. It had been reported (Vittt et al, 2003) that the concentration of metals in produced water was field specific and related to the age and geology of the rock formation from which the oil and gas were produced. We thus attribute the high Fe level at the Port Harcourt terminal to the geology of the rock formation there.

TABLE 1: Physico-chemical characteristics of produced water at Port Harcourt and

\begin{tabular}{|c|c|c|c|c|}
\hline \multicolumn{5}{|c|}{ Warri terminals } \\
\hline S/no & Parameter & $\begin{array}{l}\text { Port Harcourt } \\
\text { terminal } \\
\text { Mean }\end{array}$ & $\begin{array}{l}\text { Warri terminal } \\
\text { Mean }\end{array}$ & $\begin{array}{l}\text { Permissible } \\
\text { limits }\end{array}$ \\
\hline 1 & $\mathrm{pH}$ & $7.49 \pm 0.28$ & $7.89 \pm 0.30$ & $6.5-8.5$ \\
\hline 2 & $\begin{array}{l}\text { Temperature } \\
{ }^{\circ} \mathrm{C}\end{array}$ & $25.50 \pm 0.35$ & $24.40 \pm 0.35$ & 30 \\
\hline 3 & TDS (mg/l) & $9205 \pm 2100$ & $8428 \pm 2332$ & 5000 \\
\hline 4 & Salinity(mg/l) & $7422 \pm 2280$ & $6108 \pm 1250$ & 2000 \\
\hline 5 & Turbidity (NTU) & $16.00 \pm 5.00$ & $37.00 \pm 9.60$ & $<15$ \\
\hline 6 & $\mathrm{DO}(\mathrm{mg} / \mathrm{l})$ & $3.07 \pm 0.40$ & $3.29 \pm 0.40$ & N.A \\
\hline 7 & $\mathrm{BOD}_{5}(\mathrm{mg} / \mathrm{l})$ & $1.72 \pm 0.48$ & $1.46 \pm 0.38$ & 125.0 \\
\hline 8 & $\mathrm{COD}(\mathrm{mg} / \mathrm{l})$ & $3.91 \pm 1.32$ & $3.91 \pm 1.32$ & 125.0 \\
\hline 9 & TSS (mg/l) & $8.50 \pm 3.40$ & $14.30 \pm 5.10$ & $<50$ \\
\hline 10 & Nitrate $(\mathrm{mg} / \mathrm{l})$ & $1.90 \pm 1.16$ & $2.50 \pm 0.26$ & N.A \\
\hline 11 & Phosphate (mg/l) & $0.52 \pm 0.12$ & $1.07 \pm 0.12$ & N.A \\
\hline 12 & Sulphate $(\mathrm{mg} / \mathrm{l})$ & $21.70 \pm 4.57$ & $14.40 \pm 4.57$ & 200.0 \\
\hline 13 & $\mathrm{THC}(\mathrm{mg} / \mathrm{l})$ & $4.72 \pm 1.59$ & $36.90 \pm 3.03$ & 20.0 \\
\hline 14 & $\mathrm{Fe}(\mathrm{mg} / \mathrm{l})$ & $1.06 \pm 0.26$ & $0.53 \pm 0.11$ & N.A \\
\hline 15 & $\mathrm{Zn}(\mathrm{mg} / \mathrm{l})$ & BDL & $0.05 \pm 0.01$ & 5.0 \\
\hline 16 & $\mathrm{Cu}(\mathrm{mg} / \mathrm{l})$ & BDL & BDL & N.A \\
\hline 17 & $\mathrm{Cr}(\mathrm{mg} / \mathrm{l})$ & BDL & $\mathrm{BDL}$ & N.A \\
\hline 18 & $\mathrm{~Pb}(\mathrm{mg} / \mathrm{l})$ & $\mathrm{BDL}$ & BDL & N.A \\
\hline 19 & $\mathrm{Ni}(\mathrm{mg} / \mathrm{l})$ & BDL & $\mathrm{BDL}$ & N.A \\
\hline 20 & $\mathrm{Cd}(\mathrm{mg} / \mathrm{l})$ & BDL & BDL & N.A \\
\hline 21 & $\mathrm{~V}(\mathrm{mg} / \mathrm{l})$ & BDL & BDL & N.A \\
\hline 22 & $\mathrm{Hg}(\mathrm{mg} / \mathrm{l})$ & BDL & BDL & N.A \\
\hline
\end{tabular}

Conclusion: The data of the physico-chemical characteristics on produced water discharged at the two terminals indicate that the aquatic environments of the oil facilities are not adversely affected by metal pollution. Desalination facilities may have to be installed to reduce the salinity of the discharged produced water.

\section{REFERENCES}

Ameriacn Public Health Association (APHA) . (2005). Standard Methods for the examination of water and wastewater. USA: Ameriacn Public Health Association (APHA).
American Society for Testing and materials (ASTM). (2005). Standards for water and environmental technology. USA: American Society for Testing and materials (ASTM).

Ali, S. A., Henry, I. R., Darlington, J. W. and Occapinti, J. (1999). Novel filtration process removes dissolved organics from produced water and meets Federal oil and Grease guidelines. Produced Water Seminar, (pp.21-22). Houston, USA. 
Amyx, J. D., Bass, J., and Whiting, R. I. .(1960). Petroleum Reservoir Engineering (4th ed.). New York: McGraw-Hill.

Cline, J. T. (1998). Treatment and discharge of produced water for deep off-shore disposal . API Produced Water management Technical Forum and Exhibition (pp. 56-60). USA: Lafayette, LA.

Cox, R. J. (1992). Subsurface disposal of produced water: an alberta perspective. Proceedings of the International produced water Symposium (pp. 47). California, USA: San Diego.

Department of Petroleum Resources (DPR). (2002). Environmental guidelines and standards for petroleum industry in nigeria . Lagos: Department of Petroleum Resources (DPR).

Dessel, V. and Omuka, P. (1994). Environmental impact of exploration and production operation on the Niger Delta Mangrove. (pp. 437-445). Lagos: Proceedings of 2nd International Conference on Health, Safety and Environment in oil and gas exploration and production.

Environmental Rights Action (ERA). (1998). Shell's double barrel attack. Lagos: Environmental Rights Action (ERA).

Ibiebele, D. D. (1986). Point source input of petroleum waste water into the Niger Delta, Nigeria. The Science of the Total Environment, 52 (3), 223-283.

Isehunwa, S. A and Onovae, S (2011). Evaluation of Produced water discharge in the Niger Delta. APRN Journal of Engineering and Applied Sciences, 6(8), 66 - 72.

Jacobs, R. P., Grant, E., Kwant, J., Marqueine, J. M. and Mentzer, E. (1992). The composition of produced water from shell operated oil and gas production in North sea. In J. P. Ray (Ed.), Produced Water. New York: Plenum Press.

Mofat, D. and Olof, L. (1995). Perception and reality, assessing priorities for sustainable development in the Niger Delta. Ambio , 3, 528-529.

Neff, J. M. (1998). Biological effects of drilling fluids, drill cuttings and produced waters, longterm environment Al effects of offshore oil and gas development, (pp. 469-538). London: Elsevier Applied Science.

Oboh, I., Aluyor, E. and Audu, T. (2009). Posttreatment of produced water before discharge using Lorffa Cylindrical Learndo. Electronic Journal of Practices and Technology , 14, 57-64.

Obunwo, C. C, Braide, S. A, Chindah, A. C, Izonfuo, W. A. L and Adiukwu, P. U (2006). Spatiotemporal variations in the water quality of a black water system, east of the Niger Delta, Nigeria. Scientia Africana, 5(2), 85 - 93.

Okoro, C. C. (2010). Microbiological impacts of produce water discharges in Nearshore shallow marine waters near Chevron's Escravos tank farm, Nigeria. American Journal of Science , $6(3), 93-101$.

Onojake, M. C. and Abanum, U. I. (2011). Evaluation and management of produced water from selected oil fields in Niger Delta, Nigeria. Journal of Water Quality Exploration and Health , 3, 91-99.

Otto, L., Zimmerman, J. T. F., Furnes, G. K., Mork, M., Saetre, R. and Becker, G. (1990). Review of the physical oceanograhpy of the North sea. Journal of Oceanography , 26 (2), 161- 238.

Tobonimi, J. K. I., Omubo, A. and Herbert, O. S. (2010). Assessment of water quality along Amadi creek in Port Harcourt, Nigeria. Sciencia Africana , 68, 153-165.

Vitt, D. H., Wider, K., Halsey, L. A. and Turetsky, M. (2003). Response of Sphagnum fuscum to nitrogen deposition: a case study of Ombrogenous peatlands in Alberta, Canada. The Byologist , 106, 235-245. 